\title{
Author Correction: Faster chiral versus collinear magnetic order recovery after optical excitation revealed by femtosecond XUV scattering
}

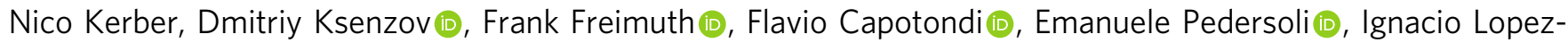
Quintas (1D, Boris Seng, Joel Cramer, Kai Litzius (1D, Daniel Lacour (D), Hartmut Zabel, Yuriy Mokrousov (D), Mathias Kläui (i) \& Christian Gutt (D)

Correction to: Nature Communications https://doi.org/10.1038/s41467-020-19613-z, published online 9 December 2020.

The original version of this Article omitted the following from the Acknowledgements:

We acknowledge the financial support from the Horizon 2020 Framework Programme of the European Commission under FET-Open Grant No. 863155 (s-Nebula).

This has now been corrected in both the PDF and HTML versions of the Article.

Published online: 04 March 2021

\footnotetext{
(c) (i) Open Access This article is licensed under a Creative Commons Attribution 4.0 International License, which permits use, sharing, adaptation, distribution and C. reproduction in any medium or format, as long as you give appropriate credit to the original author(s) and the source, provide a link to the Creative Commons license, and indicate if changes were made. The images or other third party material in this article are included in the article's Creative Commons license, unless indicated otherwise in a credit line to the material. If material is not included in the article's Creative Commons license and your intended use is not permitted by statutory regulation or exceeds the permitted use, you will need to obtain permission directly from the copyright holder. To view a copy of this license, visit http://creativecommons.org/licenses/by/4.0/.
}

(๑) The Author(s) 2021 